RECONSTRUCTING THE WORLD 



\section{RECONSTRUCTING THE WORLD}

Southern Fictions and

U.S. Imperialisms, 1898-1976

\section{Harilaos Stecopoulos}

CORNELL UNIVERSITY PRESS

Ithaca and London 


\section{Copyright $(92008$ by Cornell University}

All rights reserved. Except for brief quotations in a review, this book, or parts thereof, must not be reproduced in any form without permission in writing from the publisher. For information, address Cornell University Press, Sage House, 512 East State Street, Ithaca, New York 14850.

First published 2008 by Cornell University Press First printing, Cornell Paperbacks, 2008

Printed in the United States of America

\section{Library of Congress Cataloging-in-Publication Data}

Stecopoulos, Harry.

Reconstructing the world : Southern fictions and U.S. imperialisms, 1898-1976 / Harilaos Stecopoulos.

p. cm.

Includes bibliographical references and index.

ISBN 978-0-8014-4685-6 (cloth : alk. paper) - ISBN 978-0-8014-7502-3 (pbk. : alk. paper)

1. American literature-Southern States-History and criticism.

2. American literature-20th century-History and criticism. 3. Southern States-In literature. 4. Literature and history-Southern StatesHistory-20th century. 5. Imperialism in literature. 6. Regionalism in literature. I. Title.

PS261.S73 2008

$810.9^{\prime} 35875-\mathrm{dc} 22$

Cornell University Press strives to use environmentally responsible suppliers and materials to the fullest extent possible in the publishing of its books. Such materials include vegetable-based, low-VOC inks and acid-free papers that are recycled, totally chlorine-free, or partly composed of nonwood fibers. For further information, visit our website at www.cornellpress.cornell.edu.

Cloth printing 10987654321

Paperback printing 1098.7654321 
for Kathy Lavezzo 
